\title{
TAJEMNICA WCIELENIA W GALIJSKIEJ LITERATURZE V WIEKU NA PRZYKLADZIE JANA KASJANA
}

Spuścizna literacka łacińskich autorów żyjących i działających na terenie Galii w V wieku zawiera tylko nieliczne teksty poświęcone tajemnicy wcielenia. $\mathrm{Z}$ tego względu traktat Jana Kasjana (360-435) O wcieleniu Pana przeciw Nestoriuszowi można uznać za wyjątkowy, choć trudno powiedzieć, czy przedstawiona tam teologia jest reprezentatywna dla teologów tego regionu ${ }^{1}$. Mimo to autorytet, jakim się ten teolog cieszył, upoważnia do potraktowania jego poglądów jako ważnego głosu w toczących się wówczas sporach teologicznych w Kościele.

\section{Jan Kasjan i powstanie traktatu $O$ wcieleniu Pana przeciw Nestoriuszo-} wi. Powstanie traktatu Jana Kasjana zostało spowodowane ,sprawą Nestoriusza”. „Wybuchła” ona, jak wiadomo, w 428 roku w Konstantynopolu i w niedługim czasie oparła się o Rzym. Znane są perturbacje związane z samym procesem powiadamiania biskupa Rzymu o wydarzeniach w Konstantynopolu oraz trudności ze zrozumieniem istoty całego zamieszania. W tych okolicznościach opat klasztoru św. Wiktora w Marsylii - Jan Kasjan, został prawdopodobnie poproszony o pomoc. Jeśli wierzyć jemu samemu, zwrócił się do niego $\mathrm{z}$ taką prośbą przyszły papież Leon, pełniący wówczas funkcje archidiakona w Rzymie ${ }^{2}$. Ponieważ nie znamy żadnych bliższych szczegółów, możemy się tylko domyślać przebiegu całej sprawy ${ }^{3}$.

${ }^{1}$ Por. De incarnatione Domini contra Nestorium, ed. M. Petschenig, CSEL 17, Wien 1888, 235-391; PL 50, 9-272. Jan Kasjan, jak wiadomo, więcej czerpał z tradycji Wschodu niz Zachodu, por. B. Studer, Dio Salvatore nei Padri della Chiesa, Roma 1986, s. 193. Traktat można uznać za „der einzige Wiederlegungsversuch des Nestorius in der kat. Kirche”, (Lexicon der antiken christlichen Literatur, hrsg. S. Döpp - W. Geerlings, Freiburg 1998, s. 336).

${ }^{2}$ Por. De incarnatione Domini, Praefatio 1, CSEL 17,235.

${ }^{3}$ Sam Jan Kasjan zdaje się powoływać na list otrzymany od Leona. W zachowanej literaturze brak jednak jakiegokolwiek śladu takiego listu. Możliwe, że Leon wyraził swoją prośbę ustnie, por. M. A. Vannier, Introduction, w; Jean Cassien, Traité de l'Incarnation contre Nestorius, Introduction, traduction du latin et annotation par M. A. Vannier, Paris 1999, 29. 
Kasjan znalazł uznanie w oczach środowiska związanego z biskupem Rzymu ze względu na swoje rozeznanie środowiska konstantynopolitańskiego i znajomość języka greckiego. W środowisku łacińskim był z kolei znany jako autor dzieł, wprawdzie z zakresu duchowości, ale w których zabierał także głos na temat toczących się sporów teologicznych ${ }^{4}$. Mógł w tej sytuacji uchodzić za człowieka co najmniej obeznanego $\mathrm{z}$ teologią. Został zatem poproszony o tłumaczenie inkryminowanych tekstów Nestoriusza, a być może także o wyrażenie swej opinii na ich temat. $Z$ dużym prawdopodobieństwem mogło to mieć miejsce w roku 429, gdy papież Celestyn musiał zabrać głos w zaistniałym sporze. Jan Kasjan otrzymał przynajmniej część dokumentacji dotyczącej Nestoriusza. Na podstawie traktatu $O$ wcieleniu Pana nie sposób odgadnąć, czy były to teksty przysłane przez samego patriarchę Konstantynopola, czy też akta wyselekcjonowane przez patriarchę Aleksandrii, Cyryla. W oparciu o dostępny sobie materiał uznał za stosowne „ostrzec Celestyna przed błędami doktrynalnymi Nestoriusza oraz zapoznać łacinników z tą herezją"5. Napisał traktat, którego celem jest nie tyle wyjaśnienie kwestii chrystologicznych, czy też wola zrozumienia punktu widzenia Nestoriusza, ile wydanie wyroku. Z góry przesądzając o jego błędnych zapatrywaniach, Kasjan ustawił się w roli obrońcy ortodoksji. Wybrał przy tym bardzo agresywny styl dyskusji, co utrudnia zarówno zrozumienie samej zwalczanej nauki, jak też jej wiernej wykładni. Sposób widzenia Jana Kasjana oddaje już sam tytuł traktatu. Zostało tam wprawdzie powiedziane, że rzecz dotyczy „wcielenia Pana”, ale też wyraźnie zaznaczone, że jest on skierowany „przeciw Nestoriuszowi”. Jak się wydaje, ta właśnie druga część tytułu, wskazująca na apologetyczny charakter tekstu, ma dla autora większe znaczenie. Stąd wśród czytelników tego tekstu pojawia się opinia, że jest to „pamflet”, w którym autor stara się wytknąć błędy swemu adwersarzowi i ukazać go, jako heretyka ${ }^{6}$.

Celem dobrego zrozumienia stanowiska Kasjana, należy też pamiętać o kontekście historycznym, w którym pisał on swój traktat. Na Zachodzie bardzo żywe były dyskusje związane z potępieniem pelagianizmu oraz Leporiusza. Doktryna Pelagiusza była szerzej znana i stanowisko Kościoła wobec niej już wypracowane. Sprawa Leporiusza miała wprawdzie mniejszy zasięg, ale z kolei dotyczyła wprost kwestii chrystologicznych. Leporiusz „obawiając

${ }^{4}$ W swoich Konferencjach podejmował aktualne wówczas tematy łaski i wolnej woli, por. A. Hamman, w: Patrologia, III, red. A. Di Berardino, Torino 1978, 494-495. Zdaniem współczesnych teologów Kasjan był w istocie miernym teologiem, a co ważniejsze „bardzo słabo rozumiał teologię wschodnią", por. A. Grillmeier, Gesù Cristo nella fede della Chiesa, vol. I, t. 2, Brescia 1982, s. 852. Niestety, na Zachodzie trudno było znaleźć teologa na marę ówczesnych potrzeb. Żył, co prawda, jeszcze św. Augustyn, ale z powodu najazdu wandalskiego, kontakt z nim był prawie niemożliwy.

5 Vannier, dz. cyt., s. 31.

${ }^{6}$ Por. tamze, 32-33. 
się, by nie zaczęto błędnie wierzyć, jakoby bóstwo zmieniło się w człowieczeństwo lub zostało zepsute na skutek pomieszania z człowiekiem, nie chciał uznać, że Bóg narodził się z niewiasty, został ukrzyżowany i cierpiał inne przypadłości ludzkiej natury" ". Błędy Leporiusza zostały napiętnowane, a on sam poddany weryfikacji. Nie miał jednak natury heretyka a błędy wynikały głównie z jego braków w teologicznym wykształceniu. W dodatku trafił na św. Augustyna, który pomógł mu zrozumieć błąd i naprowadził go na katolickie myślenie. Leporiusz zgodził się z tym, że „Słowo Boże, to jest jednorodzony Syn Boży, tak stał się synem człowieczym, że żaden nie przemienił się w drugiego, ale obaj pozostali w swojej substancji. W ten sposób Bóg w człowieku cierpiał to, co ludzkie, zachowując jednak w sobie pełnię bóstwa"8. Leporiusz został formalnie oczyszczony $\mathrm{z}$ zarzutu herezji, ale jego wystąpienie wyostrzyło uwagę współczesnych i zaowocowało podejrzliwym traktowaniem wszystkich wątpliwości chrystologicznych. Dla Jana Kasjana przypadek Leporiusza jest bardzo pouczający, choć przypisuje mu cechy heretyka?.

W dorobku samego Jana Kasjana omawiany traktat jest ostatnim z jego dzieł. Został prawdopodobnie ukończony przed sierpniem 430 roku, co sugeruje wzmianka o Nestoriuszu jako jeszcze biskupie Konstantynopola ${ }^{10}$. Z całą pewnością jest mniej znany od jego poprzednich dzieł, a czasem wręcz ledwie zauważany ${ }^{11}$. Trudno określić wpływ zawartych w tym traktacie rozwiązań na sam sposób procedowania Rzymu z Nestoriuszem oraz na późniejszą tradycję teologiczną. Według opinii jednego ze współczesnych znawców przedmiotu „osąd Kasjana jako eksperta nie otwiera żadnej nowej perspektywy na kwestie teologiczne jego czasów”, a niektóre jego twierdzenia mogły przyprawić o „ból głowy archidiakona Leona"12.

Poglądy Nestoriusza - z którymi polemizował - znał Jan Kasjan prawdopodobnie z materiałów dostarczonych mu z Rzymu. Spośród tych materiałów można zidentyfikować fragmenty listu Nestoriusza do papieża Celestyna, oraz fragmenty kilku jego mów ${ }^{13}$. Jan Kasjan poznał na podstawie tych materiałów istotne wypowiedzi chrystologiczne swego adwersarza. Dysponował też wiado-

${ }^{7}$ Augustinus, Epistula 219,3, CSEL 57,430.

${ }^{8}$ Tamże. Współczesna krytyka jest skłonna przyznać, że autorem sformułowań użytych przez Leporiusza był sam św. Augustyn. Sformułowania te były na tyle trafne, że można je uznać, ,za pierwszy szkic Tomus ad Flavianum”, por. Grillmeier, dz. cyt., s. 848.

${ }^{9}$ Por. De incarnatione Domini I 4-5, CSEL 17,238-239.

${ }^{10}$ Tak przynajmniej sądzi F. Bordonali, Cassiano Giovanni, DPAC I 616. Jeżeli ten termin przyjąć, to możliwe, że papież Celestyn pisząc swoją odpowiedź dla Nestoriusza dysponował traktatem Kasjana. W Lexicon der antiken christlichen Literatur, s. 336, przyjęto, że było to przed latem 431 roku.

${ }^{11}$ Por. Hamman, Patrologia, dz. cyt., s. 490; M. Daniluk - P. Paciorek, Jan Kasjan, EK VII 800 .

12 Por. Grillmeier, dz. cyt., s. 853.

13 Chodzi o Mowy VIII, IX, XIV, XVI. Szerzej zob. Vannier, Introduction, dz. cyt., s. 52. 
mościami pochodzącymi z samego Konstantynopola na temat zaistniałych tam wydarzen ${ }^{14}$. Nie można też wykluczyć, że przyjaciele dostarczyli mu już istniejące pisma Cyryla Aleksandryjskiego przeciw nauce Nestoriusza, znane w Konstantynopolu, co nie tylko pozwalało Kasjanowi lepiej poznać poglądy herezjarchy, ale mogło w znaczący sposób wpłynąć na ton dyskusji i na jego koncepcje chrystologiczne ${ }^{15}$.

Na formę i dobór argumentów wpływ miał też cel, z jakim Kasjan pisał swój traktat. Jego zaś celem nie było zrozumienie i rzeczowe przedstawienie punktu widzenia oraz chrystologii patriarchy Konstantynopola, ale wyszczególnienie jej najbardziej dyskusyjnych punktów, ze swoją interpretacją. Niewykluczone też, że dostrzegając groźbę herezji Nestoriusza, chciał przed nią przestrzec środowisko łacińskie. Taki zamiar tym bardziej tłumaczyłby sposób, w jaki prezentował w Traktacie o wcieleniu Pana samą osobę jak też twierdzenia patriarchy Konstatntynopola. Przy pisaniu swego traktatu Jan Kasjan miał do dyspozycji Libellus emendationis Leporiusza, z którego zresztą chętnie na początku korzystał. Dysponował zatem szkicem wypracowanej przez św. Augustyna chrystologii, a przede wszystkim mógł się dobrze zapoznać $\mathrm{z}$ istotą problemu, który był źródłem kłopotów zarówno Leporiusza, jak też Nestoriusza na Wschodzie ${ }^{16}$. O ile jednak św. Augustyn uchwycił sens trudności Leporiusza, to Kasjan albo nie był w stanie, albo nie chciał się nad tym zastanawiać. Wolał oskarżyć Leporiusza, a w jeszcze większym stopniu Nestoriusza, o czysto heretyckie intencje ${ }^{17}$. Przy takim nastawieniu nie dziwi chęć wykazania przede wszystkim bezbożności nie tylko twierdzeń, ale też samego ich autora.

2. Charakterystyka traktatu. Cały traktat jest żywą polemiką z kilku twierdzeniami przypisywanymi Nestoriuszowi. Jan Kasjan wielokrotnie cytuje te same inkryminowane zdania i za każdym razem usiłuje przy pomocy innych argumentów ukazać ich heretycki sens. W efekcie „kompozycja traktatu jest mało zrozumiała, plan niejasny, a teologiczna wymowa użytych sformułowań niepewna" 18 .

${ }^{14}$ Informatorzy pochodzili z kręgów niechętnych Nestoriuszowi i sympatyzujących z Cyrylem z Aleksandrii, zob. Vannier, Introduction, dz. cyt., s. 54.

15 Por. E. Amann, L'affaire Nestorius vue de Rome, „Revue des Sciences Religieuses” 23 (1949) 233.

${ }^{16}$ Obydwaj eksponowali rozdzielność natur w Chrystusie, choć brakowało im odpowiednich ku temu sformułowań, por. Grillmeier, dz. cyt., s. 848. Na temat Leporiusza zob. Libellus emendationis, CCL 64, 111-123 lub PL 31, 1221-1230; F. de Beer, Une tessère d'orthodoxie, le „Libellus emendationis" de Leporius, REA 10(1964) 145-185; A. Chavasse, Le dossier Leporius et le livre X $d u$ „De Trinitate” pseudo-athanasien, REB 74(1964) 316-318; F. Gori, Il „Libellus emendationis” di Leporio, ,Augustinianum” 24(1994) 201-206; DThC IX 434-440.

17 Por. De incarnatione I 2,4-5.

${ }^{18}$ Hamman, dz. cyt., s. 491. 
Formalnie traktat $O$ wcieleniu Pana składa się z siedmiu ksiąg, co jeszcze samo w sobie nie jest czymś nadzwyczajnym, jednak podział taki nie jest umotywowany ani treścią, ani racjami formalnymi. Jest to całkiem dowolny wybór autora, który nie potrafi w sposób jasny uzasadnić przyjętego przez siebie układu. Podane przez niego uzasadnienie jest wprawdzie oryginalne, ale mało przekonywające. Na początku VI księgi Jan Kasjan stwierdza, że pięć poprzednich ksiąg zostało napisanych przez analogie do pięciu chlebów ze sceny rozmnożenia chleba (Mt 14,17-21) i potrzeba jeszcze dwóch dalszych, by nie zapomnieć też o dwóch rybach ${ }^{19}$. Mętne tłumaczenie jakoby chodziło o przyrządzenie ,duchowego pokarmu”, przydatnego ludziom szukającym Boga, koresponduje wprawdzie z zagmatwanym sposobem argumentacji wielu innych kwestii w tym dziele, ale sprawy nie wyjaśnia. Nie dziwią zatem spekulacje, jakie pojawiają się wśród badaczy usiłujących odgadnąć zamiar autora. Wszyscy zgadzają się, że w grę wchodziła trudna do zidentyfikowania symbolika $^{20}$, trudno tylko ustalić jej sens. Można się zgodzić $\mathrm{z}$ opinią, że Kasjan wybrał liczbę siedem $\mathrm{z}$ racji jej symboliki biblijnej, a samo uzasadnienie ma charakter drugorzędny.

Po krótkim wstępie, w którym zostały przedstawione okoliczności powstania dzieła, w księdze I Jan Kasjan określa charakter herezji, w jaką popadł Nestoriusz. Po zestawieniu jej z innymi herezjami chrystologicznymi IV i początku V wieku, dochodzi do wniosku, że Nestoriusz ,mówi dokładnie to samo, co mówili przed nim pelagianie" ${ }^{21}$. W następnych czterech księgach, formalnie ze sobą związanych, Kasjan w oparciu o teksty biblijne usiłuje, na swój sposób, obalić herezję Nestoriusza. Najpierw próbuje wykazać przy pomocy tekstów Starego i Nowego Testamentu, że „Pan nasz Jezus Chrystus, w czasie swego przebywania w ciele i na ziemi, był Bogiem"22 i w konsekwencji Maryi przysługuje tytuł „Theotokos”. W następnej kolejności, tą samą metodą, w sposób mniej lub bardziej klarowny, będzie się starał wykazać, że „,był On zawsze Bogiem, również zanim się przyodział w ciało" ${ }^{23}$.

W księdze VI Autor zmienia sposób argumentowania: powołując się na Tradycję, wyrażoną zwłaszcza w symbolu wiary, jaki przy swoim chrzcie miał składać Nestoriusz ${ }^{24}$, oskarża swego adwersarza o dopuszczenie się zdrady wiary. Analiza artykułu tego symbolu, poświęconego osobie Syna Bożego, każe przyjąć bóstwo Chrystusa, tożsame z bóstwem Syna Bożego. W ostatniej, VII księdze, Jan Kasjan raz jeszcze próbuje wykazać patriarsze Konstantynopola, że błędnie rozumie tajemnicę wcielenia oraz teksty, które ją wyraża-

19 Por. De incarnatione VI 2,1.

${ }^{20}$ Por. Vannier, Introduction, dz. cyt., s. 33-35.

21 De incarnatione, I 3,3.

22 Tamże, IV 1,2, CSEL 17,286: „cum in carne atque in terra esset, deum probavimus”.

23 Tamże: ,ante nativitatem corpoream tantum deum”.

${ }^{24}$ W tym celu Jan Kasjan powołuje się na „Symbol Antiocheński”. 
ją. W tej części polemizuje z szerszą gamą wypowiedzi Nestoriusza. Dla wykazania ich błędności przytacza argumenty biblijne oraz patrystyczne. Autorytet św. Hilarego, św. Atanazego, św. Grzegorza z Nazjanzu, św. Augustyna i św. Jana Chryzostoma mają ostatecznie pognębić Nestoriusza. Tak więc, te dwie ostatnie księgi są ze sobą związane, choć prezentują odmienny typ argumentacji niż pierwsze pięć ksiąg.

Zgodnie z przyjętą konwencją, Autor nie szczędzi ostrych słów kierowanych pod adresem adwersarza, choć starannie unika wymieniania jego imienia. W zakończeniu zaś, powołując się na swoje związki z Konstantynopolem, zwraca się do „swoich współobywateli przez miłość do ojczyzny i braci w jednej wierze”, by się odwrócili od ,wilka drapieżnego" i „,nawet nie dotykali tego, co od niego pochodzi”, 25 .

3. Herezja Nestoriusza. Z nauki Nestoriusza Jan Kasjan eksponuje dwa zasadnicze wątki. Podstawowy błąd patriarchy Konstantynopola miałby polegać na tym, że widział on w Chrystusie tylko człowieka, który został uznany lub adoptowany przez Boga: „Nowy autor herezji, która wcale nie jest nową, utrzymuje, że nasz Pan i Zbawca urodził się tylko jako człowiek" ${ }^{26}$. W chwili chrztu w Jordanie miałby zostać namaszczony na Chrystusa, a po zmartwychwstaniu zostałby ubóstwiony. „Syn Boży, Pan Jezus Chrystus - miał nauczać Nestoriusz - narodził się z Dziewicy tylko jako człowiek. Następnie wstąpił na drogę cnoty i prowadził życie święte i pobożne. Dzięki temu świętemu życiu, zasłużył na to, że Boży majestat złączył się z Nim" "27. Natura, która się narodziła z Dziewicy była mimo wszystko wyjątkowa, bo pod-

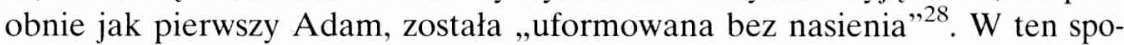
sób Chrystus był obrazem Boga w takim samym stopniu, jak pierwszy człowiek. Dzięki temu mogło się przez Niego dokonać „odnowienie zniszczonego podobieństwa" 29 .

Redukując Chrystusa narodzonego z Dziewicy do wymiarów tylko ludzkich, popada Nestoriusz - zdaniem Jana Kasjana - w błąd pelagianizmu, a także umieszcza się w jednym szeregu ze wszystkimi wcześniejszymi herezjami, negującymi bóstwo Chrystusa ${ }^{30}$. Wszystkie one oddzielają Chrystusa narodzonego z Maryi od Syna Bożego, uznając tego pierwszego tylko za człowieka.

25 De incarnatione VII 31,3, CSEL 17,390.

26 Tamże, I 3,3, CSEL 17,240: „novus nunc non novae haereseos auctor, qui dominum salvatoremque nostrum solitarium hominem natum esse".

27 Tamże V 1,1, CSEL 17,302: ,dominus Iesus Christus, natus ex virgine, homo tantummodo solitarius crederetur, et arrepta postmodum virtutis via id eum pie ac religiose vivendo obtinuisse, ut dignus per hanc vitae sanctimoniam fieret cui se maiestas divina sociaret".

28 Tamże, VII 6,1, CSEL 17,361. Kasjan cytuje w tym wypadku fragment homilii Nestoriusza.

29 De incarnatione VII 6,4, CSEL 17,362.

${ }^{30}$ Por. tamże, I 3,3. 
Zgodnie zatem z zasadą, którą przyjmuje Kasjan: „gdy neguje się cokolwiek w Bogu, neguje się wszystko, wyznając, że On nie zawsze był Bogiem, mówiąc tym samym, że nie był Nim nigdy"31.

Druga fałszywa teza Nestoriusza wyraża się - w ocenie Jana Kasjana w zanegowaniu Maryi tytułu „Theotokos” i na przyznaniu jej tylko tytułu "Christotokos"32. Podstawowy argument przemawiający za tego typu twierdzeniami Nestoriusza ma charakter rozumowy: nikt nie może zrodzić kogoś wcześniejszego od siebie ${ }^{33}$. Może on przybrać charakter bardziej filozoficzny, gdy się będzie twierdzić, że „narodzony winien być współistotny temu, który go zrodził" ${ }^{34}$. Przyjęcie wspomnianych założeń prowadzi, zwłaszcza w konfrontacji z tekstami biblijnymi oraz tradycją, do wielu dalszych błędnych wniosków. Interpretując, jak wskazuje Kasjan, w tym duchu symbol wiary dochodzi się do konieczności przyjęcia istnienia dwóch Chrystusów. Wyznajemy przecież „wierzę w Boga Ojca wszechmogącego i w Jezusa Chrystusa jego Syna”, a potem wyznajemy wiarę w Jezusa Chrystusa narodzonego z Maryi. „Zatem jeden jest Chrystus narodzony z Boga i drugi narodzony z Maryi" ${ }^{35}$. Tak zdefiniowany błąd Nestoriusza Jan Kasjan usiłuje obalić przy pomocy świadectw biblijnych oraz analizy artykułów wiary zawartych w symbolu wiary. Cała ta argumentacja będzie zmierzała do wykazania bóstwa Chrystusa, narodzonego z Maryi, i tym samym do uznania Go za tożsamego z Synem Bożym, istniejącym odwiecznie.

Dokumentacja biblijna przytoczona w traktacie jest nad wyraz obfita i różnorodna. Autor Traktatu o wcieleniu Pana skorzystał z całego szeregu zapowiedzi starotestamentalnych, w których będzie mowa o przyjściu na świat Syna Bożego. Szczególną rolę w tym dowodzie odgrywa tekst o Zwiastowaniu, interpretowany w łączności z licznymi wypowiedziami, które go objaśniają. Kluczowe są słowa anioła „Duch Święty zstąpi na ciebie i moc Najwyższego osłoni Cię. Dlatego też to, co się z Ciebie narodzi będzie święte i będzie nazwane Synem Bożym" (Łk 1,35) ${ }^{36}$. Jest w tych słowach oczywista zapowiedź, że narodzony będzie Synem Bożym, a interwencja Najwyższego wyjaśnia sposób, w jaki to może nastąpić. Interwencja Boża powinna stanowić wystarczające wyjaśnienie i uzasadnienie tytułu „Theotokos”37. Mimo to Kasjan przytacza, dla potwierdzenia swego stanowiska, jeszcze inne wypowiedzi starotestamentalne, zapowiadające przyjście Mesjasza (Iz 9,5; Iz 9,14; Ml 3,8),

${ }^{31}$ Tamże, VI 14,2, CSEL 17,341: ,in deo qui partem denegaverit totum negat.

32 Tamze, II 2,1.

33 Por. tamże.

34 Tamże, VI 13,1, CSEL 17,340: „homousios parienti debet esse nativitas”.

35 Tamże, VI 15,1, CSEL 17,342: ,alter ex deo Christus, alter ex Maria, duo ergo in sententia tua Christi sunt".

${ }^{36}$ Tamże, II 2,3, CSEL 17,247.

37 Por. tamże, II 2,8. 
którego „nie można oddzielić od Boga” ${ }^{38}$. Natomiast liczne wypowiedzi św. Pawła na różny sposób ukazują boskość Chrystusa ${ }^{39}$. Podobną wartość ma świadectwo ,pierwszego" ze względu na godność i wiek apostoła Piotra (Mt $16,16)^{40}$. Nadto synostwo Boże Chrystusa potwierdzone zostało w chwili Jego chrztu w Jordanie (Mt 3,16-17) ${ }^{41}$. W tym ostatnim przypadku Kasjan, jak się wydaje, forsując nieco tekst eksponuje bóstwo Chrystusa, które Go wprost przepełnia.

Szczególną rolę dowodową w Traktacie o wcieleniu Pana pełni credo antiocheńskie, będące, zdaniem Kasjana, wyznaniem wiary „w którym został ochrzczony i odrodzony heretyk" ${ }^{, 2}$. Przyjmując chrzest po złożeniu tego wyznania wiary Nestoriusz ,zgodził się” na zawarte tam prawdy wiary. Te z kolei to nic innego, jak skrót tego, co powiedział Bóg w Starym i Nowym Testamencie ${ }^{43}$. Zgodnie z zawartymi w credo artykułami wiary Syn Boży, współistotny Ojcu, istniejący przed wiekami, narodził się z Dziewicy Maryi. „Przyszedł ze względu na nas" - zostało powiedziane w symbolu. A skoro przyszedł, to znaczy istniał wcześniej, czego nie można powiedzieć o człowieku ${ }^{44}$.

4. Tajemnica wcielenia. Wierząc tytułowi, można by się spodziewać, że Jan Kasjan będzie się starał w sposób w miarę wszechstronny przedstawić rozumienie tej tajemnicy. Wbrew tak rozbudzonym oczekiwaniom nie przedstawia on jednak pełnej i spójnej nauki o wcieleniu Syna Bożego. Z całą determinacją broni prawdy o jedności Jezusa Chrystusa, o której mówi jeden z artykułów symbolu chrzcielnego, istniejącego w Trójcy Świętej przed czasem z Tym, którego znamy z czasów ziemskiej działalności. Ten sam Syn Boży, wspótistotny Ojcu, narodził się z Maryi Dziewicy, umarł, zmartwychwstał i wstąpił do nieba. Według Kasjana, w tajemnicy Wcielenia „to, co należy do bóstwa (czyli bóstwo Syna współistotnego, jego relacje z Ojcem i pośrednictwo w dziele stworzenia) staje się tym, co należy do historii świata" ${ }^{45}$. Uzasadnienia dla

38 Tamże, II 3,4-7, CSEL 17,250-251.

39 Św. Pawła nazywa Kasjan „najsolidniejszym i najprawdziwszym świadkiem Chrystusa” (II 4,1). Najważniejszym natomiast jego tekstem jest Tt 2,11-13, a zwł. słowa: „ukazała się łaska Boga, nasz Zbawiciel” w łączności z ostatnimi słowami „wielki Bóg i Zbawiciel Jezus Chrystus”. Podobnie wymowne są słowa Rz 9,3-5; Ga 1,1; 4,4; 2 Kor 5,10 w łączności z Rz 14,10-11, z których wynika, że „trybunał Chrystusa” jest „trybunałem Boga”.

${ }^{40}$ Por. De incarnatione III 12,4-6.

${ }^{41}$ Por. tamze, III 16,2-6.

42 Tamze, VI 3,1, CSEL 17,327.

${ }^{43}$ Por. tamże, VI 4-5.

${ }^{44}$ Por. tamże, VI 8,3-4, CSEL 17,334. Jakkolwiek niektóre wypowiedzi Jana Kasjana w tym względzie są mało precyzyjne, np. ,in uno tamen domino Iesu Christo et homo ante perpetuus et deus mortuus praedicatur” (VI 22,5, CSEL 17,349). Pojęcie „homo perpetuus” jest trudne do zrozumienia i do przethumaczenia.

45 Por. Grillmeier, dz. cyt., s. 854. 
tej prawdy wiary szukał Kasjan w tekstach biblijnych, ale tego samego dowodzi, jego zdaniem, prawda o odkupieniu, czy też historia zbawienia realizująca się na naszych oczach. Fundamentalny w tym dowodzeniu staje się tekst św. Pawła „gdy nadeszła pełnia czasu, zesłał Bóg Syna swego, zrodzonego z niewiasty, podległego Prawu” $(\mathrm{Ga} 4,4)^{46}$. Syn współistotny Ojcu, jeżeli ma przyjść na świat, nie może tego uczynić w swoim bóstwie, ale musi wejść w historię poprzez wcielenie. Domagało się tego również dzieło odkupienia, którego Chrystus miał dokonać. Bóg dla „uzdrowienia” rodzaju ludzkiego nie mógł wysłać tylko człowieka. Tego dokonać mogło tylko odwieczne Słowo Boże, które w tajemnicy Wcielenia zjednoczyło się z Chrystusem ${ }^{47}$. Czas, miejsce i sposób wybrał sam Bóg. Żadna epoka ani osoba nie miała na to wpływu. Nie determinował Go też żaden porządek. „Bóg przyszedł na świat tak, jak chciał, kiedy chciał i z niewiasty, którą sam wybrał"48.

Przyjście na świat Chrystusa było jedyne w swoim rodzaju i niepowtarzalne, poza wszelkim ludzkim porządkiem. O tej wyjątkowości stanowiło samo poczęcie, w którym udział brała Maryja i „moc Ducha Świętego”. Tajemnicę tego, co wówczas się dokonało, wyrażają - zdaniem Jana Kasjana - słowa z Listu do Hebrajczyków, odnoszące się wprost do Melchizedeka, który był „,bez ojca, bez matki” (Hbr 7,3). Odniesione do Chrystusa, prowadzą do wniosku: „Chrystus narodził się w bóstwie bez matki, a w swoim ciele jest bez ojca" "49. Sposób, w jaki się to dokonało, można tylko wyrazić biblijnym wyrażeniem, o „osłonięciu przez moc Najwyższego" 50 . Uzasadnieniem całego wydarzenia pozostaje moc Boża, która wielokrotnie w historii, a także w stworzeniu, przekraczała porządek stworzony ${ }^{51}$ : „Bóg narodził się w człowieku. Ciało narodzone z Dziewicy nie istniało zawsze, ale Bóg, który jest zawsze przyszedł wziąwszy ciało z Dziewicy" ${ }^{, 2}$.

Przez fakt wcielenia dokonała się faktyczna kenoza Słowa Bożego. Przyjęło ono bowiem, zgodnie ze świadectwami biblijnymi, ,,postać sługi”, a przyjmujacc warunki ludzkie ,przywiązało się do szubienicy” ponosząc śmierć na krzyżu ${ }^{53}$. Złączenie z „ciałem”, które nastąpiło w momencie wcielenia, ma skutek trwały. Od tej chwili wręcz trudno będzie rozróżnić Chrystusa „który jest ciałem, i tego, który jest Bogiem", czego dowodzi historia św. Pawła pod Damaszkiem ${ }^{54}$.

${ }^{46}$ Por. De incarnatione, VI 8,1, CSEL 17,334.

47 Por. tamże, IV 4,2, CSEL 17,290.

48 Tamże, VII 2,3, CSEL 17,354: ,deus ergo ut voluit, quando voluit et ex qua voluit advenit”.

49 Tamże, VII 14,6, CSEL 17,370: ,sicut in deitate est sine matre, ita in corpore est sine patre generatus".

50 Tamze, VII 17,3, CSEL 17,373.

${ }^{51}$ Na dowód przytacza cuda, znane z dziejów biblijnych, por. tamże, VII 5. CSEL 17.359.

52 De incarnatione, VI 20,2, CSEL 17,346-347: „non enim caro illa quae ex carne virginis nata est semper fuit, sed deus qui semper fuit ex carne virginis in carne hominis advenit".

${ }^{53}$ Por. tamże, VI 20.2. CSEL 17.346

${ }^{54}$ Por. tamże, III 6,3-4, CSEL 17,267. 
O trwałości tego połączenia pouczył sam Chrystus, który - zdaniem Kasjana - mówił o nierozłączaniu tego „co Bóg złączył” (Mt 19,6). Słowa te znaczą: „nie rozdzielajcie tego, co Bóg złączył we mnie”. implikuje sposób patrzenia na Chrystusa, czyli chrystologię w ujęciu Jana Kasjana.

5. Chrystologia Jana Kasjana. Podstawowym celem dowodzenia przeprowadzonego przez Jana Kasjana było odparcie błędnych twierdzeń Nestoriusza. $\mathrm{Na}$ tym koncentruje się jego wysiłek w zbieraniu dowodów i formułowaniu wniosków. Ponieważ nie zrozumiał, a może nawet nie chciał, istoty trudności swego adwersarza, trudno przy takim podejściu szukać u niego pozytywnego wykładu chrystologicznego. Można znaleźć trochę twierdzeń z tego zakresu, które pozwalają na skonstruowanie przynajmniej założeń chrystologii, w wizji reprezentowanej przez Kasjana ${ }^{56}$.

Nade wszystko Kasjan bronił z całą stanowczością bóstwa Chrystusa, popadając przy tym nawet w niebezpieczną skrajność. Użyte przez niego sformułowania są niejednokrotnie mało precyzyjne i niosą niebezpieczeństwo wieloznaczności, choć jednocześnie nie brak sformułowań bardzo trafnych. Tak jest w przypadku demonstrowania bóstwa Chrystusa. Jan Kasjan, komentując istotne w jego dowodzeniu słowa św. Pawła o niemożliwości poznania Chrystusa „według ciała” (2 Kor 5,16), pisze wprost, że jest to skutkiem tego, iż „,natura ciała została zmieniona w duchową substancję": „Wszystko to, co wcześniej miało dwie substancje, stało się jedną potęgą, gdyż jest rzeczą niezaprzeczalną, że Chrystus, który został ukrzyżowany w naszej słabości, żyje teraz mocą majestatu bożego" "57. Zjednoczenie bóstwa z naturą ludzką Chrystusa staje się do tego stopnia nierozdzielne, że Kasjan nie zawaha się mówić o jednej osobie: „Zrozum zatem, że Chrystus jest Bogiem. A gdy dostrzeżesz, że substancja Chrystusa i Boga jest nierozdzielna, to uznaj również, że jest nierozdzielna osoba" ${ }^{58}$. W niektórych powyższych stwierdzeniach ich autor ociera się wprost

55 Tamże, V 11,1, CSEL 17,319. Wydaje się, że w tym przypadku Kasjan inspirował się zdaniem Orygenesa, wyrażonym w Przeciw Celsusowi VI 47.

${ }^{56} \mathrm{Na}$ temat chrystologii Jana Kasjana por. m.in.: V. Codina, El aspecto cristológico en la espiritualidad de Juan Casiano, Roma 1966; L. Dattrino, Note „De incarnatione” di Giovanni Cassiano, w: Historiam pictura refert. Miscellanea A. R. Veganzones, Roma 1994, 201-210; L. Stangore, La cristologia antinestoriana di Giovanni Cassiano, Napoli 1945; M. A. Vannier, Jean Cassien a-t-il fait oeuvre de theologien dans le „De Incarnatione Domini”, RevSR 66(1992) 119-131; taż, La christologie du Cassien, w: Jean Cassien. Traité de l'Incarnation. Introduction, dz. cyt., $60-70$.

57 De incarnatione, III 3,5, CSEL 17,264-265: „natura enim carnis in spiritalem est translata substantiam [...] quidquid fuerat prius substantiae duplicis factum est virtutis unius... ex maiestate divina".

58 Tamże, III 7,3, CSEL 17,270: ,intellige ergo indubitanter Christum deum et vides inseparabilem Christi ac dei esse substantiam, inseparabilem quoque agnosce esse personam”. 
o monofizytyzm ${ }^{59}$, co zapewne nie było jego zamiarem. Powodowała nim zapewne obawa, by nie dopuścić myśli o dwu osobach w Chrystusie. Podobne trudności ma Kasjan w wyrażeniu prawdy o Słowie, które w chwili wcielenia „stało się ciałem”. Broniąc bóstwa Chrystusa powie wprost „nie ma żadnego dystansu między Chrystusem a Słowem "60. Według niego „z tak zjednoczonego przez tajemnicę wcielenia Chrystusa i Słowa Bożego, stał się z dwu tych rzeczywistości jeden Syn Boży"

Lektura, zwłaszcza pierwszych ksiąg traktatu Kasjana, może prowadzić do wniosku, że w próbach „zdefiniowana podmiotu wcielenia” jest on podobnie bezradny i ocierający się o błędne sformułowania, jak Nestoriusz ${ }^{62}$. Dużo łatwiej przychodzi mu wyrazić prawdę o bóstwie tak Słowa przed wcieleniem, jak i po wcieleniu. Dzieje się to kosztem minimalizowania człowieczeństwa. Broni bóstwa, które nie zostało w żaden sposób uszczuplone w „,ciele człowieka"63, natomiast nie występował w ten sam sposób w obronie człowieczeństwa. Był to zabieg poniekąd zamierzony, bo Kasjan zdecydowanie występował przeciw redukowaniu natury Chrystusa do czysto ludzkiej. W ten jednak sposób spowodował, że „przedstawia Chrystusa ogołoconego z człowieczeństwa"64. W miarę jednak pisania swego dzieła znajduje coraz to trafniejszą terminologię dla ukazania zarówno bóstwa, jak i człowieczeństwa Chrystusa, a tym samym jego chrystologia nabiera pełniejszego wyrazu. Zdaniem współczesnych znawców przedmiotu, najwartościowsze pod tym względem są rozdziały, w których Kasjan analizuje credo antiocheńskie.

Podstawowa dla Kasjana stała się ta część credo, która mówi, że „wierzę [...] w naszego Pana Jezusa Chrystusa, Jego jedynego Syna i pierworodnego z całego stworzenia, narodzonego z Niego przed wszystkimi wiekami, a nie stworzonego, prawdziwego Boga z Boga prawdziwego, współistotnego (homousios) Ojcu. On przyszedł dla nas i narodził się z Maryi Dziewicy, został ukrzyżowany pod Poncjuszem Piłatem i pogrzebany. Trzeciego dnia zmartwychwstał, według Pism. Wstąpił do nieba i przyjdzie sądzić żywych i umartych" ${ }^{\prime 65}$.

Słowa Symbolu w pełni harmonizują z fundamentalnymi dla całej kwestii słowami św. Pawła „gdy nadeszła pełnia czasów, Bóg posłał swojego Syna,

59 Por. Grillmeier, dz. cyt., s. 853; Vannier, Introduction, dz. cyt., s. 67.

${ }^{60}$ De incarnatione, IV 5,2, CSEL 17,290: „nullam penitus inter Christum et verbum esse distantiam".

${ }^{61}$ Tamże, IV 4,2, CSEL 17,290: „sic unito per sacramentum incarnationis Christo et verbo dei factus est Christus et verbum dei unus ex re utraque filius dei".

${ }^{62}$ Por. Grillmeier, dz. cyt., s. 854.

${ }^{63}$ Por. De incarnatione, VI 19,1, CSEL 17,345.

${ }^{64}$ Por. Grillmeier, dz. cyt., s. 857.

${ }^{65}$ Por. De incarnatione VI 3,2, CSEL 17,327. Vannier w komentarzu do tego miejsca (s. 201, n. 1) zauwaza, ze Kasjan, podobnie jak Hilary z Poitiers, pisze „homousios” a nie „homoousios”. 
uczynionego z niewiasty, poddanego Prawu" (Ga 4,4). Wyrażają one prawdę o tym, że Syn współistotny Ojcu chcąc przyjść na świat, musiał przyjąć drogę wcielenia. W konsekwencji możemy powiedzieć, że „Bóg się narodził, Bóg cierpiał, Bóg zmartwychwstał" ${ }^{\text {"6r }}$. Do tego sposobu mówienia upoważnia, zdaniem Kasjana, zasada synekdochy: „cokolwiek więc powiesz o Panu Jezusie, mówisz o całym: „ogłaszasz w Synu Bożym syna człowieczego, a w synu człowieczym Syna Bożego. Zgodnie bowiem z zasadą synekdochy całość jest pojmowana od części, a część nazywana jest od całości”67. Chcąc zatem być w zgodzie z prawdą zawartą w symbolu wiary należy wierzyć, „w Boga Ojca, wierzyć w Syna Bożego, wierzyć w jednego rodzącego i jednego zrodzonego, Pana wszystkiego Jezusa Chrystusa, współistotnego Ojcu, narodzonego w bóstwie i narodzonego w ciele, podległego podwójnemu narodzeniu, ale tego samego majestatu, Stwórcy wszystkiego stworzenia, który został zrodzony z Ojca, a następnie z Dziewicy" "68.

Kasjan znalazł też odpowiedź na trudności wysuwane przez Nestoriusza, w związku z używaniem tytułu Theotokos. Jak już wspomniano, Nestoriusz miał negować boskie macierzyństwo Maryi wychodząc z założenia, ze „zrodzony winien być tej samej natury co rodzący”. Kasjan w odpowiedzi na to stwierdza: „Pan Jezus Chrystus jest współistotny zarówno swemu Ojcu, jak i swojej Matce. W rzeczywistości [...] według bóstwa był współistotny Ojcu, a według ciała był współistotny swej matce" ${ }^{\text {"9 }}$. Sposób, w jaki się to dokonało, wyjaśnia Kasjan odwołaniem się do działania Ducha Świętego, który „uświęcając wnętrze Dziewicy i tchnąc tam mocą swego bóstwa, wprowadził się w naturę ludzką i z nią się zmieszal" "70.

Najwięcej trudności sprawia Kasjanowi wyrażenie prawdy o jedności hipostatycznej w Chrystusie. Terminologia, której używa dla zaznaczenia pełni człowieczeństwa i pełni bóstwa, jest w Traktacie często nieporadna, a bywa, że myląca. Mówi o Chrystusie w następujących słowach: „człowiek narodzony z człowieka i Boga, poczęty przez Ducha Świętego zstępującego na Dziewi-

${ }^{66}$ De incarnatione, VI 9,2, CSEL 17,336: ,deum utique natum, deum passum, deum resurrexisse".

${ }^{67}$ Tamże, VI 23,1, CSEL 17,349: „Quidquid ergo de domino Iesu dixeris, totum dicis, et in dei enim filio filium hominis et in hominis filio dei filium nuncupabis, tropo scilicet synecdoches, quo et a parte totum intelligitur et a toto portio nominatur". Jan Kasjan powołuje się przy tym na Pismo Święte (Rdz 15,13), które też stosuje zasadę synekdochy.

68 Por. tamże, VI 19,2, CSEL 17,345.

69 Tamze, VI 13,1-2, CSEL 17,340-341: ,interim quia homoousion parienti dicis nativitatem esse debere, ego dominum Iesum Christum homoousion fuisse dico patri pariter et matri [...] secundum divinitatem enim homoousios patri, secundum carnem autem homoousios matri”.

${ }^{70}$ Tamze, II 2,3, CSEL 17,248: ,spiritus enim sanctus virginis interiora sanctificans est in his potentiam divinitatis suae spirans humanae se inseruit miscuitique naturae". Dowód z natury (np. o powstawaniu pszczół VII 5,1), który dla poparcia swego stanowiska przytacza Kasjan, lepiej potraktować jako ciekawostkę. 
cę, i dzięki mocy Najwyższego osłaniającego ją swoim cieniem, będąc w ten sposób synem człowieka i Boga"71. Jest to „Bóg, który przywdział ciało”, czy też „Bóg w ciele” ${ }^{72}$. Dla wyrażenia tej tajemnicy wprowadza mało zrozumiałe pojęcie „homo dominicus”. Oznaczać ono ma byt (naturę ludzką?), który przylgnął do Boga i do tego stopnia połączył się z Bogiem, że „nie można w żaden sposób i nigdy oddzielić człowieka od Boga, ani w męce oddzielić Boga od człowieka" ${ }^{, 73}$.

$$
* * *
$$

Traktat o Wcieleniu Pana przeciw Nestoriuszowi Jana Kasjana stanowi, jak widać, ilustrację sporów, a jednocześnie trudności, jakie istniały w kształtowaniu się chrystologii chalcedońskiej. Trudno określić, na ile spełnił swoje zadanie, zgodnie z myślą, dla której powstawał. Z całą pewnością dla późniejszych pokoleń stanowi użyteczne źródło umożliwiające poznanie trudności, na jakie napotykano w dyskusjach na temat chrystologii V wieku. Stanowisko Jana Kasjana jest tym ciekawsze, że reprezentuje on łacińską teologię, choć uchodzi on przy tym za znawcę teologii greckiej. Dorobek Kasjana pod tym względem trudno uznać za imponujący. Z całą pewnością na uwagę zasługuje charakter biblijny jego chrystologii. Na tym zresztą polegał też główny zarzut kierowany pod adresem Nestoriusza, którego błąd miał właśnie wynikać ze złego rozumienia Pisma Świętego ${ }^{74}$. Terminologia używana w traktacie jest nieprecyzyjna (zwłaszcza użycie terminów: natura, substancja, osoba), a sam sposób narracji mało jasny, co w efekcie może prowadzić do nieporozumień. Taki był, jak się wydaje, jeden z zasadniczych kłopotów wszystkich teologów tamtych czasów. Natomiast niektóre z wyjaśnień, zwłaszcza tajemnicy wcielenia, zasługują na uwagę.

${ }^{71}$ De incarnatione, III 16,4, CSEL 17,283: „, homo ergo ille ex homine ac deo natus, spiritu sancto in virgine descendente et virtute altissimi obumbrante conceptus, ac sic hominis et dei filius".

72 Tamze, II 3,8; II,3,9, CSEL 17,252: ,,in carne dominus”; ,deus indutum pro nobis carnem”.

${ }^{73}$ Tamże, VI 22,2, CSEL 17,348: „quis a deo nec in passione possit deum ab homine discernere".

${ }^{74}$ Por. tamże, VII 17,1, CSEL 17,352. 


\section{IL MISTERO DELL'INCARNAZIONE IN GIOVANNI CASSIANO}

(Riassunto)

Giovanni Cassiano è l'autore del trattato De Incarnazione Domini contra Nestorium libri VII, scritto come una risposta alla domanda dell'arcidiacono di Roma, Leone. Nel suo scritto Giovanni Cassiano esamina i più scuotanti tesi di Nestorio: negazione della divinità al Cristo e negazione del titolo Theotokos alla sua Madre. Con gli argomenti presi dalla Sacra Scrittura e dal credo di Antiochia l'autore del trattato cerca di dimostrare la piena divinità di Cristo. Con l'aiuto della communicatio idiomatum atribuisce alla Maria il titolo Theotokos. Nel scritto viene presentata anche la cristologia di Giovanni Cassiano la sua interpretazione dell'incarnazione. La sua cristologia però non ha unità e in certe parti è molto oscura. Essa non offre alcuna base per fondare una cristologia della umanità di Cristo. Tuttavia, alcune frasi lasciano intravedere gli interessanti soluzioni terminologici e concettuali a proposito. 